\title{
Svjedočanstvo Ignacija Radića o Hrvatskom katoličkom pokretu
}

\begin{abstract}
Ignacij(e) Radić (Sv. Vid-Miholjice kod Malinske, 28. VIII. 1876. - Porat kod Malinske, 30. VII. 1965.), samostanski franjevac trećoredac i glagoljaš, postao je svećenikom 1899., najprije djelujući kao vjeroučitelj u Velom Lošinju, a potom kao profesor u gimnazijama svoje zajednice na Galevcu (Školjiću) i Krku. Od samih početaka Mahnićeva Hrvatskog katoličkog pokreta Radić mu se pridružio i bio jednim od glavnih suradnika časopisa Hrvatska straža (1903.). Kad je došao u Krk, Mahnić ga je izabrao za osobnog ispovjednika i prihvatio njegovu pomoć u uređivanju listova Hrvatska straža i Svećenička zajednica. Dosljedan Mahnićevu načelu da Crkva mora pratiti cjelokupnu ljudsku djelatnost te vjernicima davati evanđeoske smjernice za život i formiranje kršćanskog nazora, proučavao je društvena kretanja u zemlji i svijetu, pisao tekstove filozofske, socijalne i ascetske tematike. Njegova bliskost Mahniću došla je do izražaja u teškim danima za Hrvatski katolički pokret, u vrijeme Prvog svjetskog rata. Posve je podržavao Mahnića i dijelio njegove tjeskobe ne samo nad sudbinom pokreta, već i katoličanstva te hrvatske narodne samobitnosti pri rasapu Habsburške Monarhije i stvaranju Države Slovenaca, Hrvata i Srba. Radićeva knjiga Doktor Antun Mahnić, biskup krčki (Slavonska Požega, 1940.) pruža vrijedno svjedočanstvo o Mahnićevoj ulozi u nastanku i djelovanju Hrvatskog katoličkog pokreta sve do njegove smrti (1850. - 1920.), a osobito u spomenutom kriznom razdoblju.
\end{abstract}

Djelo fra Ignacija Radića (1876. - 1965.), franjevca trećoreca glagoljaša, Doktor Antun Mahnić, biskup krčki (Slavonska Požega, 1940.), valja uključiti u literaturu kojom se koriste povjesničari u osvjetljivanju uloge biskupa Antuna Mahnića (1850. - 1920.) u povijesti Hrvatskog katoličkog pokreta. Radić je bio blizak Mahniću jer je sedam godina potkraj Mahnićeva života bio njegov ispovjednik, a pridružio mu se od samih početaka Hrvatskog katoličkog pokreta i prihvatio njegova gledišta do te mjere da je postao jednim od istaknutijih suradnika časopisa Hrvatska straža. Sâm je Mahnić tražio Radićevu pomoć u uređivanju Hrvatske straže i časopisa za svećenike Svećenička zajednica. Radić je bio četvrt stoljeća mlađi od Mahnića. Rodio se 28. kolovoza 1876. u Sv. Vidu-Miholjicama kod Malinske. Među franjevce trećorece glagoljaše stupio je 1893. U Zadru je završio bogoslovni studij, a Mahnić ga je 1899. u Krku zaredio za svećenika. Kao mlad 
svećenik bio je vjeroučitelj u Velom Lošinju, a potom nastavnik u trećoredskoj gimnaziji, najprije na Galevcu (Školjiću) i zatim u Krku. Prihvatio je Mahnićevu ideju da Crkva mora pratiti cjelokupnu ljudsku djelatnost te vjernicima davati evanđeoske smjernice za život i formiranje kršćanskog nazora, pa je proučavao društvena kretanja u zemlji i svijetu te pisao filozofske, socijalne i ascetske tekstove. Njegova bliskost Mahniću došla je do izražaja u teškim danima za Hrvatski katolički pokret, u vrijeme Prvog svjetskog rata. Posve je podržavao Mahnića i dijelio njegove tjeskobe ne samo nad sudbinom pokreta, već i Katoličke crkve u Hrvata te hrvatske narodne samobitnosti u rasapu Austro-Ugarske Monarhije i stvaranju Države Slovenaca, Hrvata i Srba. Zato Radićeva knjiga Doktor Antun Mahnić, biskup krčki (Slavonska Požega, 1940.) pruža vrijedno svjedočanstvo o Mahnićevoj ulozi u nastanku, određivanju usmjerenosti i djelovanju Hrvatskog katoličkog pokreta, pa sve do njegove smrti, a osobito u spomenutom kriznom razdoblju.

Radićeva je knjiga o Mahniću prije svega njegovo neposredno, osobno svjedočanstvo o Mahnićevim posljednjim godinama života, kad je Radić vrlo često bio s njime. Valja upozoriti na to da je Radić k tome sabrao svjedočanstva bliskih Mahnićevih suradnika, kao što su: Mahnićev generalni vikar Krčke biskupije Mate Polonijo, osnivač prvih učeničkih akademskih društava po Mahnićevu programu, Ivan Butković1 te prvi urednici Hrvatske straže - Ante Alfirević ${ }^{2}$ Fran Binički. ${ }^{3} \mathrm{Ne}$ smije se previdjeti da se sam Radić na prvim stranicama svoje knjige žali riječima upućenima čitatelju da je: ,prošlo dvadeset godina da je dr Antun Mahnić, biskup

1 Ivan Butković (Vrbnik, 25. I. 1876. - Split, 21. VI. 1954.) završio je studij bogoslovlja u Gorici i kao mlad svećenik na Krku uređivao gospodarski polumjesečnik Pučki prijatelj. Mahnić ga je poslao na studij u Beč, gdje je na njegov poticaj osnovao Hrvatsko katoličko akademsko društvo „Hrvatska“ i pokrenuo časopis $L u c ̌$, kojem je bio prvi urednik (1905./1906.). Djelovao je kao predavač na visokim bogoslovnim školama u Zadru do talijanske okupacije, a zatim u Splitu. Uređivao je i list akademske katoličke mladeži u Zadru Mladost. Usp. MATIJEVIĆ 2002c: 799.

2 Ante Alfirević (Kaštel Sućurac, 26. I. 1875. - Zagreb, 17. I. 1945.) teološko je školovanje završio doktoratom filozofije i teologije na Gregorijanskom sveučilištu u Rimu (1902.). Za svećenika je zaređen 1901., pa je u Splitu obavljao svećeničke službe; osnovao je Hrvatsku štedionicu i djelovao u seljačkom zadrugarstvu. Godine 1919. pristupio je isusovcima, obavljajući važne odgojne službe u crkvenim zavodima u Zagrebu i Sarajevu. Hrvatsku stražu uređivao je od 1903. do 1906. te od 1914. do 1918. Usp. MATIJEVIĆ 2002a: 790.

3 Fran Binički (Mašaluk kod Gospića, 11. VII. 1875. - Lički Osik, sredinom 1945.) umro je pod nerazjašnjenim okolnostima kao žrtva nove Jugoslavije. Teološko školovanje završio je 1902. doktoratom u Innsbrucku. Od 1902. do 1919. bio je profesor crkvene povijesti i kanonskog prava u biskupijskoj Bogoslovnoj školi u Senju. Uređivao je Hrvatsku stražu u prvim godina njezina izlaženja te je bio jedan od najbližih suradnika biskupa Mahnića. Bio je član Hrvatske pučke stranke, a iz političkih razloga 1934./1935. boravio je u zatvoru. Surađivao je s brojnim katoličkim časopisima i listovima. Uspješno je prevodio s talijanskog i njemačkog jezika. Važnija su mu djela: Grgur Ninski (Senj, 1900.), Katarina kraljica bosanska (Sarajevo, 1906.), Krštenje Hrvata (Senj, 1910.), Katolička crkva i znanost (Mostar, 1923.), Predziđe kršćanstva (Zagreb, 1924.) i dr. Usp. MATIJEVIĆ 2002b: 795. 
krčki, zauvijek zaklopio svoje trudne oči. I kao da su mu ruševine svjetskog rata zamele svaki trag; na oca katoličkog pokreta već se rijetko tko sjeća“. Zatim napominje: „Osjećao sam potrebu da liku velikoga biskupa postavim okvir jedne čedne biografije“. Odmah je zacrtao opseg Mahnićeva djelovanja. Najprije naglašava da u njemu gleda: „Vođu koji iz redova lajičke i svećeničke ruke sakuplja mladu četu u boj protiv beznačelnog liberalizma, koji je onda vladao", a onda nabraja i druge dimenzije Mahnićeva djelovanja te u njemu vidi: „revnog pastira duša, organizatora đaštva i svećenstva, žarkog domoljuba, mučenika i prognanika“" (str. 7). Radić je u svojoj knjizi o Mahniću najveću pozornost posvetio Hrvatskom katoličkom pokretu (ukupno 69 stranica: 33-79, 88-104, 176-184). Za Radića je drugo pitanje po važnosti u Mahnićevu zanimanju bila duhovna i kulturna izgradnja svećenstva (39 stranica: 109-113, 141-176). Zatim ističe Mahnićevu brigu za dobro vjernika (str. 125-128), a naglašava i njegovo domoljublje, koje osobito dolazi do izražaja u brizi za glagoljicu ${ }^{4}$ i političku angažiranost potkraj Prvog svjetskog rata (25 stranica: 72-78, 129-140, 185-193). Čitatelj će sigurno zamijetiti da Radić s puno poštovanja izvješćuje o Mahnićevim patničkim danima u političkoj internaciji (str. 193-199) te se trudi prikazati njegov duhovni lik (str. 200-230), zaključujući svoju knjigu pozivom: „da dr Antun Mahnić bude uzdignut do časti oltara". ${ }^{5}$

\section{Hrvatski katolički pokret počinje kao učenički pokret}

Radić je uvjeren da je opravdano biskupa Mahnića držati pokretačem i osnivačem Hrvatskog katoličkog pokreta jer je on na pragu 20. stoljeća pokrenuo hrvatske učenike i učenički pokret. Počeo je drukčije od drugih koji su imali iste nakane. Obraća se učenicima, organizira i posvećuje im posebnu pozornost. Postaje pravim „đačkim biskupom“ “ jer mu je bilo jasno da o sudbini naroda i njegovu

$4 \quad$ Mahnićeva Staroslavenska akademija i njegovo izdavačko uporište Leonovo društvo sa sjedištem u Senju ujedinile su se 1928. s Hrvatskom bogoslovskom akademijom. Zadaća Leonova društva bila je promicanje kršćanske filozofije i znanosti, osnivanje zaklade za podupiranje mladih pisaca i briga oko izdavanja enciklopedije (MATAUŠIĆ 1990: 327-352). Budući da je u sastavu Hrvatske bogoslovske akademije rad bio organiziran u tri odjela: opći bogoslovni odjel, filozofski odjel i staroslavenski odjel za studij liturgijskih knjiga, ona je podržavala taj sadržaj djelovanja.

5 Poslije Mahnićeve smrti 1920. Radić je u svojoj franjevačkoj pokrajinskoj zajednici bio njezin tajnik, vijećnik i provincijski vikar. Za vrijeme Drugoga svjetskog rata bio je generalni povjerenik za trećoredske samostane pod talijanskom okupacijom, dok ga te talijanske vlasti nisu internirale na otočiću i tvrđavi Mamuli, pri ulazu u Boku kotorsku. Umro je 30. srpnja 1965. u Portu (Dubašnica) na otoku Krku, a ostavio je više od 200 bibliografskih jedinica, od čega 17 knjiga i brošura.

6 RADIĆ 1940: 80. 
povijesnom razvoju odlučuju škole i sveučilišta. Samo oni koji ispravno budu odgajali mlade ljude imat će kroz jedno ili dva desetljeća za sobom sav narod. Inteligencija je mozak naroda, stoga svaka obnova naroda mora početi od buduće inteligencije. Za Mahnića su to bili studenti teologije i drugi akademičari, koji su već stajali na vratima života. Njihov je osobni primjer također od odlučujuće važnosti i za učenike u srednjim školama.

Radić stoga naglašava da je Mahnić organizirao laičko društvo „odozdo“, koje nastoji potaknuti najšire slojeve katoličkih vjernika, posebno intelektualce, $\mathrm{i}$ oblikovati njihovu svijest o njihovoj ulozi u životu Katoličke crkve. ${ }^{7}$ On se jedini odmaknuo od deklaracija i zaključaka Prvog hrvatskog katoličkog kongresa 1900. u Zagrebu. Tako je postao začetnikom pokreta koji je Crkvi u Hrvata dao velik broj laika, koji su sve svoje umne i fizičke sposobnosti posvetili Bogu i svome narodu. Nadahnuti kršćanskim načelima i ispunjeni gorljivošću za Božju i narodnu stvar, ti su laici razvili apostolat, koji nas danas ispunjava divljenjem jer je ubrzo prerastao u opći Hrvatski katolički pokret.

Prvi njegov pouzdanik u tom nastojanju bio je svećenik njegove biskupije Ivan Butković, kojega je poslao na studij u Beč. Već nekoliko mjeseci nakon dolaska u Beč Butković javlja Mahniću kako je ondje 12. svibnja 1903. održana osnivačka skupština Hrvatskog katoličkog akademskog društva „Hrvatska“. Članovi udruge „Hrvatska“" nastojali su pokrenuti učenički časopis, a u tome im je odmah pomogla Mahnićeva Hrvatska straža, pozivajući hrvatsku mladež na suradnju. Koncem 1905. u Beču je doista počeo izlaziti učenički list $L u c ̌$, tiskan u Mahnićevoj tiskari „Kurykta“ $u$ Krku. ${ }^{8}$ List je na sebe preuzeo trostruku zadaću: ,provesti organizaciju katoličke mladeži, vježbati mlade sile u radu na peru i osvojiti simpatije hrvatske javnosti za katoličku mladež“. Luč je među hrvatske učenike unosio Mahnićeve ideje, postavši ujedno glasilom mlade generacije katoličkih pjesnika i pisaca sve do završetka Drugog svjetskog rata. Prva zadaća novog lista bila je povezati u čvrstu organizaciju oduševljenu srednjoškolsku i sveučilišnu mladež. Zato je redakcija

\footnotetext{
ŠANJEK 1996: 433.

2. RADIĆ 1940: 73.
}

8 Te je godine u Krku već počela izlaziti i Hrvatska straža. Mahnić je bio uvjeren da neprijateljski i protuvjerski tisak može uspješno paralizirati samo dobar katolički tisak. Potonji u svoj djelokrug mora uključiti „znanost i filozofiju, apologetiku i beletristiku, sociologiju i narodnu ekonomiju, nabožnu i zabavnu knjigu, novinarstvo i politiku“ - jednom riječju, sve ono „što može čovjeka zanimati i bilo kako utjecati na njegovo mišljenje i djelovanje“-zaključuje A. Mahnić (RADIĆ 1940: 71). Zato je osnovao katolička tiskarska poduzeća, kao što su Leonovo i Pijevo društvo. Nakon dolaska u Krk Mahnić je odmah osnovao svoju vlastitu tiskaru „Kuryktu“, koja je postala prava propovjedaonica za modernog biskupa. Već u prosincu 1899. u „Kurykti“ izlazi prvi broj Pučkog prijatelja, dvomjesečnika gospodarskog usmjerenja, namijenjenog seljačkom svijetu. Ondje je 1901. počeo izlaziti mjesečnik za svećenike Sanctisima Euharistia, koji se 1911. stopio sa Svećeničkom zajednicom u jedan list. Učenički list Luč također je 1905. počeo izlaziti u „Kurykti““. 
Luči naglašavala potrebu sastanka hrvatske studentske mladeži, do čega je i došlo tri godine kasnije na Trsatu, kad su postavljeni temelji organizaciji svih hrvatskih katoličkih učenika. U Zagrebu je osnovano Katoličko akademsko društvo „Domagoj“. Njegovo geslo postaje: Bog, narod i socijalna pravda. Posebnu je brigu „Domagoj“ posvetio oživotvorenju socijalne pravde, što je inače predstavljalo jedno od osnovnih načela Hrvatskog katoličkog pokreta jer on nije razvijao svoje djelovanje samo na vjerskom, već i na socijalnom i ekonomskom polju. ${ }^{9}$ Kako bi se javnost upoznala s novim pokretom, u Zagrebu je 1907. održan velik zbor svih hrvatskih i slovenskih katoličkih učenika, koji je donio program organiziranja učenika i u provinciji. Već 1908. domagojci u Splitu za seljačku mladež pokreću list Mladost, u Zagrebu za nižeškolce mjesečnik Krijes, za hrvatske katoličke učenice Proljetno cvijeće, a za ženski obrazovani svijet list Za vjeru i dom. Demokratsku vlastitost Hrvatskog katoličkog pokreta potvrđuje i nastanak Seniorata, tj. dijela već završenih katoličkih studenata, nazvanih „seniori“. Njihova konstituirajuća skupština održala se 1913. u Ljubljani. Prema nacrtu biskupa Mahnića, Seniorat je postao vrhovno tijelo hrvatskoga katoličkoga omladinskog pokreta. Zadaća mu je bila nadzirati Hrvatski katolički pokret, započinjati nove pothvate, voditi brigu o njegovoj ideologiji, kao i o sveukupnom daljnjem razvoju. Budući da je Hrvatski katolički pokret nastao „odozdo“, bez upletanja hijerarhije, biskupi uopće nisu ulazili ni u njegovo djelovanje, ni u njegovo organizacijsko uređenje. Seniori su, dakle, imali „slobodne ruke“ u svom djelovanju, osim, dakako, u moralnom i doktrinarnom području, gdje je nadzor biskupa bio posve razumljiv. Tu su dužnost obavljali svećenici duhovnici. Po uzoru na druge slične pokrete u svijetu, seniori su postupno svoju djelatnost proširivali i na druga područja. Tako se u žarištu njihova zanimanja našlo selo i radništvo. ${ }^{10}$

\section{Idejni program Hrvatskog katoličkog pokreta}

Mahnić je rodom bio Slovenac te je do imenovanja krčkim biskupom 1896. bio profesor teologije i odgojitelj mladeži u sjemeništu u Gorici. Ondje se isti-

9 U svom je krilu „Domagoj“ odnjihao velik broj znanstvenika, književnika, karakternih i samoprijegornih ljudi. U prvom redu valja spomenuti dr. Rudolfa Eckerta i dr. Petra Rogulju. Obojica su svoj život potpuno posvetila Bogu. Zavjetovali su se da neće osnivati obitelji, kako bi u svom radu za Boga i domovinu bili potpuno slobodni. U toj plejadi „domagojaca“ valja spomenuti i druga značajna imena ljudi, koji su zbog svoga javnog ispovijedanja vjere žrtvovali visoke položaje i sveučilišne katedre: Stjepan Markulin (1885. - 1940.), odvjetnik; Petar Grgec (1890. - 1962.), pisac; Ljubomir Maraković (1887. - 1959.), književni kritičar; Ivan Merz (1896. - 1928.), blaženik; Avelin Ćepulić (1896. - 1936.), liječnik; Josip Andrić (1894. - 1967.), publicist i skladatelj; Velimir Deželić, ml. (1888. - 1976.), pravnik i publicist; Juraj Šćetinec (1898. - 1939.), sociolog; Mario Matulić (1896. - 1937.), odvjetnik; Djuro Ljubić (1903. - 1933.); Djuro Sudeta (1903. - 1927.), pjesnik; Mate Ujević (1901. - 1967.), leksikograf i pisac; Zvonimir Remeta (1909. - 1964.), pisac.

10 RADIĆ 1940: 84. 
cao kao plodan neoskolastički i apologetski pisac. Osnovao je i uređivao reviju Rimski katolik (od 1888. do 1896.) sa zadaćom suzbijanja liberalizma. Polazeći od kršćanskih i katoličkih načela, Mahnić je oštroj kritici podvrgnuo tadašnje vodeće slovenske književnike. Utjecaj tog časopisa očito nije bio neznatan jer su ga austrijske liberalne vlasti zabranile čitati u slovenskim školama. Kako bi ga udaljile iz Slovenije, promaknule su ga za biskupa u Krku. Njegovim imenovanjem za biskupa namjeravale su zadati i smrtni udarac glagoljici, koja je upravo u Krčkoj biskupiji imala svoju dugu povijest. Namjere im se, međutim, nisu ostvarile. Mahnić je brzo upoznao pitanje glagoljice i prihvatio najviša crkvena rješenja, stoga je glagoljica u njemu dobila svoga pobornika i promicatelja.

Mahnić je 1900. sudjelovao na Prvom hrvatskom katoličkom kongresu u Zagrebu, ali svoj rad u Sloveniji nije pokušao preporučiti kao primjer kojim valja poći Crkva među Hrvatima. Punih šest godina nakon svog dolaska u Krk biskup je šutio i proučavao prilike u Hrvatskoj, posebno one u žurnalistici i književnosti. Zaključivši da javni život Hrvatske potresaju isti problemi kao i u Sloveniji, odlučio je zahvatiti u vjerske i kulturne prilike, navijestivši odlučan otpor protukršćanskom liberalizmu i u Hrvatskoj. Odluku je ostvario osnivanjem revije Hrvatska straža, tromjesečnog časopisa za kršćansku prosvjetu. Ono što je Rimski katolik bio za Slovence, to je Hrvatska straža postala za Hrvate: „Preko nje on je zasnovao, organizovao i utvrdio svoj hrvatski katolički pokret", dobro primjećuje Ignacij(e) Radić. ${ }^{11}$

Radić naglašava da je Mahnić odmah na početku Hrvatskog katoličkog pokreta pokazao kako se potonji zasniva na trima idejama: vjerskoj, narodnoj i demokratskoj. Vjerska je prvotna i valja je graditi sustavnim filozofskim i teološkim studijem kako bi se tako mogla suprotstaviti liberalizmu. ${ }^{12}$ Radić se na početku Mahnićeve biografije suočio s dvama važnim pitanjima. Prvo, tj. sâmo osnivanje pokreta riješio je uspješno za svoj program, o čemu piše Radić pod naslovom „Među đacima“. Zatim postavlja pitanje programa te nastanka i početnog razvitka Hrvatskog katoličkog pokreta pod naslovom „Otac katoličkog pokreta“.${ }^{13}$ Dok se trudio obrazložiti to pitanje, Radić je isticao kako je ishodište programa njegova vjernost kršćanskoj filozofiji, što znači da je prihvatio poziv pape Leona XIII., koji se svojim pismom „Aeterni Patris“ iz 1879. zauzeo za obnovu skolastike, odnosno za neoskolastiku. ${ }^{14}$ Ta filozofija nadahnjuje i opravdava njegovo suprotstavljanje liberalizmu, koji je zaprijetio Crkvi sekularizacijom. ${ }^{15}$ Tako Radić vidi

\footnotetext{
11 MARDEŠIĆ 2002: 253-271.

12 RADIĆ 1940: 39-42.

13 Isto: 178.

14 ŠAGI-BUNIĆ 1970: 118.

15 RADIĆ 1940: 80.
} 
samo filozofske razloge Mahnićeva suprotstavljanja liberalizmu i karakteru tog suprotstavljanja. To je doista opravdano jer je Mahnić od pape Leona XIII. zaista prihvatio njegovu spomenutu okružnicu, kojom traži obnovu teološkog studija i poziva na povratak skolastičkoj filozofiji, neoskolastici. ${ }^{16}$ Premda je Mahnić Katoličkom pokretu dao zadaću praćenja cjelokupne ljudske djelatnosti te davanja vjernicima evanđeoskih smjernica za život i formiranje kršćanskog nazora, Radić nije zapazio crkveno-povijesne razloge takvog Mahnićeva cilja. Mahnić o njima nije mnogo pisao, ali ih je uočio i o njima vodio računa. Bilo mu je jasno da se poslije Prvog vatikanskog koncila isprepleću dva osnovna modela prisutnosti Crkve i katolika u suvremenom svijetu. Nijedan od njih nije nadilazio ideal srednjovjekovnog monolitnog društva, u kojem su se sva područja društvenog života prilagođavala kršćanskim vjerskim, socijalnim i kulturnim načelima. Mahnić je vezan uz poimanje povijesti koje nije tražilo novo rješenje odnosa među Crkvom i društvom. Prianja uz klasičnu kršćansku teologiju povijesti Augustinove De civitate Dei, po kojoj je sva povijest neprestani rat između Božje i sotonine države, između dobra i zla, između Krista i Antikrista. Od pape Leona XIII. i njegova pisma „Rerum novarum“ prihvatio je nove socijalne i političke ideje. Od njega je prihvatio i zadaću izgradnje novog kršćanskog društva, tj. rekristijanizaciju sveukupnog društva preko katoličkih škola, katoličkih stranaka, katoličkih socijalnih i kulturnih ustanova. Naravno, prema tome je bila usmjerena i obnova filozofije u skolastičkom duhu. Ipak, valja upozoriti da je Mahnić osuđivao liberalizam jer je očito vodio do sekularizacije na vjerskom polju. Stoga se Mahnić suprotstavio liberalizmu, ponešen pismom pape Pija IX., naslovljenom „Syllabus“(1864.), koje je zastupalo borbeno katoličanstvo i pozivalo na rat s liberalizmom, a osobito je tražilo radikalno suprotstavljanje katoličkom liberalizmu. ${ }^{17}$

\section{Mahnićevo poštovanje demokratskih odnosa}

Premda je bio crkveni dostojanstvenik, Mahnić je bio zastupnik i graditelj demokracije. Sve se to očituje već na samom početku Hrvatskog katoličkog pokreta jer Mahnić povjerava uredništvo Hrvatske straže Anti Alfireviću i Franu Biničkom, a Ivana Butkovića poslao je u Beč da se proučavanjem filozofije ,spremi za svoju buduću misiju i da istodobno poradi oko organizacije hrvatskog katoličkog akademskog društva". ${ }^{18}$ Ovo osobito povjerenje u suradnike ubrzo je donijelo plodove. Hrvatski je katolički pokret potkraj Mahnićeva života imao četiri akademska društva i dva sveučilišna kluba sa 150 članova, 10 bogoslovskih zborova s 300 članova, 41 kongregaciju u srednjim školama s preko 3.000 članova i 60

\footnotetext{
16 Isto: 33-43; ŠAGI-BUNIĆ 1970: 118.

17 PIRC 1990: 122-123; ŠAGI-BUNIĆ 1970: 119; MARDEŠIĆ 2002: 253-271.

18 RADIĆ 1940: 84.
} 
omladinskih seljačkih društava s 3.000 članova. Na njihovu je čelu stajalo 150 seniora. Tako organiziran Hrvatski katolički pokret u to je vrijeme predstavljao neospornu snagu. Tada se razmišljalo da će i u najvišem hrvatskom političkom tijelu, Saboru, svoja mjesta uskoro zauzimati ljudi iz Hrvatskog katoličkog pokreta. Izborni kotarevi u kojima su se trebali kandidirati katolički laici već su također bili određeni. Sve je to bilo usmjereno prema osnivanju političke stranke koja je doista osnovana u vrijeme Mahnićeve internacije, tj. bez njegova neposrednog sudjelovanja. Radić ne zaboravlja naglasiti da je Mahnić nakon svojeg dolaska na Krk osnovao tiskaru „Kurykta“ jer je vjerovao u novinstvo. Smatrao je potrebnim što prije omogućiti vlastiti tisak. ${ }^{19}$ Njegovo je uvjerenje prihvatio i Hrvatski katolički pokret, pa se koristio njegovom tiskarom. Pred početak Prvog svjetskog rata raspolagao je s jednim dnevnikom, 5 tjednika, 3 polumjesečnika, 14 mjesečnika i 1 dvomjesečnikom, a svojim je utjecajem određivao fizionomiju još 5 dnevnika, 5 tjednika i 7 mjesečnika te 1 lista neredovitog izlaženja. Prema toj statistici, snaga je katoličkog tiska bila gotovo jednaka snazi liberalnog novinstva, a pučki katolički časopisi bili su gotovo pet puta jači od onih liberalno orijentiranih.

\section{Mahnić se bori za hrvatska narodna prava}

Radić još bilježi Mahnićeve političke čine potkraj i nakon završetka Prvog svjetskog rata. Najprije treba spomenuti tzv. Spomenicu papi Benediktu XV. Nastala je još 1915. u Rijeci, a Bernardin Škrivanić i Jozo Milošević uručili su je papi. U toj Riječkoj spomenici mole papu da je preda na uvid državnicima kad se budu sastali na konferenciji mira nakon završetka rata. U njoj se ističe da Hrvati i Slovenci traže uređenje Monarhije prema principu trijalizma, zahtijevajući svoju neovisnost o vodećim narodima u Austro-Ugarskoj. Propadne li Monarhija, žele osnovati svoju državu i to sporazumno s pobjedničkim državama. ${ }^{20}$

Zatim je uslijedila Svibanjska deklaracija. Potpisali su je zastupnici iz Hrvatske 30. svibnja 1917. u bečkom Carevinskom vijeću. Njome su zahtijevali da Slovenci, Hrvati i Srbi s područja Monarhije i nadalje ostanu u njoj prema principu trijalizma. Ako se Monarhija raspadne, valja slijediti jugoslavensku ideju i tražiti oblike ujedinjenja Slovenaca, Hrvata i Srba. Mahnić je potpisao tu deklaraciju, a austrijska ga je javnost osudila pod optužbom da agitira za jugoslavensku ideju na štetu katolicizma. ${ }^{21}$ Austro-Ugarska nije odobrila Svibanjsku deklaraciju, ali je u Hrvatskoj tako ostala dilema: samostalna Hrvatska ili Jugoslavija? Hrvatski katolički pokret izgradio je katoličko hrvatstvo, koje je pronosila Hrvatska pučka

\footnotetext{
Isto: 70.

20 Isto: $187,188$.

21 Isto: 189.
} 
stranka. ${ }^{22}$ Ostvarena je Jugoslavija. Jedan je dio mladeži iz redova Hrvatskog katoličkog pokreta i seniora, zbog protuhrvatske i protuslavenske austrijske politike, bio oduševljen jugoslavenstvom. To je oduševljenje za samo nekoliko godina nakon rata splasnulo te su se ljudi brzo otrijeznili. Nova Država Slovenaca, Hrvata i Srba započela je sa svojom diskriminatorskom politikom prema Hrvatima, koja će uroditi tragičnim posljedicama. ${ }^{23}$

Odmah nakon rata Talijani su okupirali Istru i Dalmaciju. Talijanska je vojska 14. listopada 1918. okupirala Krk i to na temelju Londonskog sporazuma iz 1915., kojim je Italiji, pod uvjetom ulaska u rat na strani saveznika, obećano dobivanje dijelova hrvatske obale i otoka. Biskup Mahnić prosvjeduje protiv okupatorskih postupaka i 3. prosinca 1918. na mirovni kongres u Pariz šalje opširni memorandum. Podiže svoj glas uime progonjenih hrvatskih svećenika i uime Hrvata otoka Krka, koji su činili $85 \%$ cjelokupnog stanovništva, ali bez uspjeha. ${ }^{24}$ Odlučuje čak poći k papi u Rim. Pod izlikom da ga vode u Senj na najbliže hrvatsko kopno, okupatorske su ga vlasti posebnim vojnim čamcem prebacile u Italiju. U Frascattiju (Eremo Camaldoli) ostao je interniran 11 mjeseci. Bolestan i slomljen, Mahnić se 12. veljače 1920. vraća u Krk, kada je već postalo jasno da je Krk izgubljen za Italiju. U srpnju iste godine odlazi u Zagreb, izmučen teškom bolešću i naporima, te nalazi sklonište u nadbiskupskom dvoru kod nadbiskupa Bauera, gdje je 14. studenoga iste godine i umro u 70 . godini. ${ }^{25}$

22 MATIJEVIĆ 1998.

23 Usp. STRECHA 1997.

24 RADIĆ 1940: 192, 193.

25 Smrću A. Mahnića Hrvatski katolički pokret izgubio je svoga utemeljitelja, vođu i učitelja. Ali iste godine gubi još jednog velikana, Petra Rogulju (1888. - 1920.) - čovjeka koji je, uz biskupa Mahnića, neosporno bio najsnažnija i najuglednija osoba. Rogulja je bio jedan od onih katoličkih laika koji je bio pripravan žrtvovati svoj život za katoličke, hrvatske i demokratske ideale. Bio je utemeljitelj Riječkih novina, prvog dnevnika mladog HKP-a, pokrenutog u Rijeci 1912. Već je tijekom prvih godina rata, zbog kritike talijanskih autonomaša i mađarskih šovinista, list bio zabranjen, ali se uredništvo seli u Zagreb. Ondje od 1914. izlazi pod imenom Novine, a urednik mu je i dalje P. Rogulja. Bio je poznat zbog svoje borbenosti i specifičnog načina pisanja. Njegova neiscrpna energija nije smalaksala niti u najtežim trenucima rata. Brinuo se za prehranu i smještaj djece iz Istre, Primorja, Hercegovine i Bosne. S franjevcem Didakom Buntićem, Đurom Basaričekom i Velimirom Deželićem, ml. razvio je karitativnu djelatnost u društvenim prostorijama „Domagoja“, u Domu katoličkog djetićkog društva. Ondje je otvorio domagojsku menzu i prenoćište za sveučilištarce. Bavio se mišlju o potrebi osnivanja vlastite političke stranke. U vrijeme rata zajedno sa Slovencima namjeravao je stvoriti Jugoslavensku pučku stranku. Ta je zamisao i ostvarena 1919. stvaranjem Hrvatske pučke stranke. Budući da se ta politička stranka stvorila bez pristanka biskupa, članovi stranke, uglavnom seniori, priznavali su nadležnost Crkve samo u pitanjima vjere i morala, dok su na vanjskom i političkom planu samostalno djelovali. Ostatak Mahnićevih suradnika, koji su preživjeli rat, nastavio je sa svojim djelovanjem između dvaju ratova. No, prilike su se promijenile. Novom vremenu pošlo se ususret s novim nadama i novim oduševljenjima. 


\section{Radićeva prosudba Mahnićeva pothvata}

Radić u dvama navratima postavlja pitanje: „da li je Hrvatski katolički pokret uspio ili nije“? Trudeći se odgovoriti, upozorava na prilike u kojima je on započeo, na okolnosti u kojima se razvio i koji je na nesreću svjetskoga rata prorijedio redove Hrvatskog katoličkog pokreta, ali ga nije uništio. Zaključuje tvrdnjom: „Posijano sjeme donijelo je nove velike plodove. Ideje je nemoguće ubiti, jer one će uvijek naći načina da ponovo ožive“" ${ }^{26}$ Tako je Mahnićev Hrvatski katolički pokret nastavio živjeti i nakon Prvog svjetskog rata u novoj, protiv volje većine hrvatskog naroda, stvorenoj državnoj tvorevini - Državi Slovenaca, Hrvata i Srba.

Radić u svojoj knjizi o Mahniću ne prati Hrvatski katolički pokret poslije Mahnićeve smrti. Bilo je to vrijeme nekoliko kriza, vanjskih i unutarnjih. Danas valja i njih poznavati kako bi se moglo prosuditi značenje pokreta u crkvenoj i političkoj povijesti Hrvata. Stoga nije naodmet spomenuti da je početkom drugog tisućljeća biskup i povjesničar Mile Bogović potaknuo na istraživanje Hrvatskog katoličkog pokreta, uvjeren da: „od njega možemo mnogo naučiti i za naše vrijeme, njime se i danas u mnogo čemu nadahnjivati“. Bogović je najprije pokrenuo studij usmjeren prema boljem poznavanju Hrvatskog katoličkog pokreta, kao i analitičkom istraživanju sadašnjeg stanja Crkve u nas. Referati tih skupova objavljeni su u dvama zbornicima. Prvi je, pod naslovom Hrvatski katolički pokret, uredio Zlatko Matijević, a tiskan je 2002. U njemu je objavljeno gradivo sa znanstvenog skupa u Zagrebu i na Krku. Drugome je naslov Mogućnosti organiziranog djelovanja vjernika laika u Hrvatskoj. Skup je održan u Osijeku, a zbornik, koji je uredio Đuro Hranić, današnji osječko-đakovački nadbiskup, objavljen je 2002. ${ }^{27}$

26 RADIĆ 1940: 90-93, 183-185.

27 Na obama je spomenutim skupovima biskup Mile Bogović izložio (a zatim su njegovi govori objavljeni u zbornicima: MATIJEVIĆ, Zlatko (ur.). 2002. Hrvatski katolički pokret. Zbornik radova s Međunarodnoga znanstvenog skupa održanog u Zagrebu i Krku od 29. do 31. ožujka 2001.; HRANIĆ, Đuro (ur.). 2002. Mogućnosti organiziranog djelovanja vjernika laika u Hrvatskoj. Simpozij hrvatskih vjernika laika, Osijek, 5. - 6. listopada 2001.) da: „taj Sabor (tj. Drugi vatikanski sabor) kao polazište za shvaćanje Crkve ne uzima hijerarhijsko uređenje nego se Crkva shvaća kao Božji narod. U tom smislu jasno da su vjernici laici dobili važniju ulogu. Teologija laikata razvijala se i nakon spomenutog Sabora. Kada se danas pomišlja na novi 'katolički pokret', misli se na polazišta današnje teologije i ekleziologije. To znači da je anakronizam jednostavno kopiranje onoga što je bilo u prvoj polovici 20. stoljeća. Za nas je taj Pokret ipak veoma poučan jer onakvu aktivnost laika vjernika i bogatstvo njihova rada mi do danas nismo postigli. Mnoge lekcije kako bismo upravo danas trebali raditi već su davno napisane. Jasno nam je da nećemo požnjeti naročite uspjehe visokim deklaracijama i zauzimanjem stavova (...). Uspjeh je u kapilarnom, sustavnom i ustrajnom radu, počinjući u prvom redu od mladih, kako je to činio krčki biskup Mahnić (...). Hrvatski katolički pokret /je/ izraz i odraz svoga vremena. Od njega možemo mnogo naučiti i za naše vrijeme, njime se i danas u mnogo čemu nadahnjivati, ali ne bi ga valjalo jednostavno presađivati, jer ovo danas nije njegovo tlo. Valja zatim istaknuti da zagovornici potrebe novoga katoličkog gibanja i udruživanja ne smatraju da to treba činiti 'protiv' nekoga (...). Ako govorimo o potrebi novog katoličkog pokreta, 
U prvom se zborniku na knjigu Ignacija Radića u svom referatu poziva samo Anton Bozanić. U drugom svesku referenti ne pokazuju da im je poznata Radićeva knjiga o Mahniću. No, što su smatrali o Bogovićevu nastojanju da u svjetlu Mahnićeva pokreta prosudi rad Crkve u Hrvatskoj nakon stjecanja samostalnosti, vrlo su jasno pokazali ostali hrvatski biskupi. Ubrzo nakon spomenutih kongresa biskup Bogović prestao je obavljati zadaću predsjednika Komisije Hrvatske biskupske konferencije za laike, a Hrvatska biskupska konferencija dodijelila mu je dužnost predsjednika Komisije za redovnike i redovnice.

\section{Zaglavak}

Valja ovaj prikaz Radićeve knjige o Mahniću završiti tvrdnjom kako Radić i 20 godina poslije njegove smrti Mahnića smatra uzorom u mnogim pothvatima, a svi su oni usmjereni prema obnovi Crkve i to napose obnovi vjernika laika, koja će ih dovesti do spoznaje njihova poziva u Crkvi i društvu, a zatim do organiziranog ostvarenja tog poziva. Budući da je Radić prije svega oduševljen član Hrvatskog katoličkog pokreta, prvenstveno želi obnoviti spomen na Mahnića, pokretača i vođu tog pokreta. Zatim, iako to izričito ne spominje, želi ukazati na Mahnića kao obnovitelja Crkve jer se od onodobnih hrvatskih biskupa razlikuje po programu obnove svećenstva i pastoralnog djelovanja, namijenjenoga populaciji biskupije. To je želio postići svojom biografijom o njemu, ali nije bio siguran da će potaknuti na takav pristup Mahniću jer svoju knjigu zaključuje pozivom na poštovanje njegova primjernog kršćanskog života svetačkih razmjera. Stoga smatra da bi ga Crkva trebala promicati do te mjere kako bi došlo do njegova proglašenja blaženim. ${ }^{28}$

mislimo na potrebu prikladnijih i boljih formula i struktura koje bi još bolje nego sada omogućile da za dobro ovoga našega naroda još bolje dođe do izražaja sva ona dobra volja koja postoji u našem kršćanskom i katoličkom narodu, a koja zbog nedostatka adekvatnih struktura ne biva realizirana, odnosno nema dovoljno poticaja da se probudi i razvije" (MATIJEVIĆ 2002: 19-20; HRANIĆ 2002: 21-22).

28 Čini se da je nama, članovima Crkve u Hrvata, teško izraziti poštovanje nečijeg života i djelovanja tako da proučavamo njegov rad. Puno nam je lakše pokrenuti proces za njegovu beatifikaciju. Tada je dovoljno promatrati duhovni lik dotičnoga. Fra I. Radić više se nije nadao da će netko učiti od Mahnića, pa traži njegovo religiozno štovanje. Piše o Mahnićevu ostvarenju triju bogoslovnih kreposti, tj. vjeri, ufanju i ljubavi (RADIĆ 1940: 203-206, 221-223). Ističe i očitovanje darova Duha Svetoga u njegovu životu, posebno darove pobožnosti, strpljivosti, prostodušnosti, poniznosti, čistoće i siromaštva (RADIĆ 1940: 206-216), a osobito naglašava Mahnićevu strpljivost i predanost Bogu tijekom podnošenja bolesti (RADIĆ 1940: 225-230). Njegovo očekivanje pokretanja Mahnićeva proglašenja blaženim nedavno se ostvarilo. No, dogodilo se i ono što Radić nije očekivao. Godine 2003. Mahnićevi su zemaljski ostaci oduzeti franjevcima trećorecima glagoljašima i preneseni u Krk. Ako su im oni na Ksaveru u Zagrebu desetljećima iskazivali dužnu počast, opravdano je pitanje je li ih bilo potrebno prenijeti u Krk. 
Ipak je Radićeva knjiga prvi primjer cjelovitog pristupa u prosudbi Mahnićeva života i djelovanja, pa je i danas upozorenje da valja cjelovito istraživati i o njemu pisati kao o obnovitelju Crkve među Hrvatima. Potrebno je također upozoriti da Radićeva knjiga o Mahniću nije samo njegovo svjedočanstvo o potonjemu kao začetniku Hrvatskog katoličkog pokreta. Budući da je Radić pisao knjigu dva desetljeća poslije Mandićeve smrti, ona je također izraz tadašnjeg mišljenja hrvatskih franjevaca trećoredaca glagoljaša o Mahniću, osobito o njegovoj ulozi u nastanku i prvim desetljećima Hrvatskog katoličkog pokreta jer bi je Radić teško napisao bez podrške svoje zajednice.

\section{Bibliografija}

HRANIĆ, Đuro (ur.). 2002. Mogućnosti organiziranog djelovanja vjernika laika u Hrvatskoj. Simpozij hrvatskih vjernika laika, Osijek, 5. - 6. listopada 2001. [Biblioteka Izvan nizova, sv. 169]. Zagreb: Kršćanska sadašnjost, Vijeće za laike Hrvatske biskupske konferencije.

MARDEŠŚĆ, Željko. 2002. Hrvatski katolički pokret i liberalizam. U Hrvatski katolički pokret. Zbornik radova s Međunarodnoga znanstvenog skupa održanog u Zagrebu $i$ Krku od 29. do 31. ožujka 2001., ur. Zlatko Matijević, 253-271. Zagreb: Kršćanska sadašnjost, Vijeće za laike Hrvatske biskupske konferencije.

MATAUŠIĆ, Juraj Mirko. Publicističko djelovanje biskupa Mahnića u Hrvatskoj. U Mahničev simpozij v Rimu, ur. Edo Škulj, 327-352. Zagreb-Celje: Slovenska teološka akademija u Rimu, Mohorjeva družba u Celju, Mohorjeva družba u Gorici, Kršćanska sadašnjost u Zagrebu.

MATIJEVIĆ, Zlatko. 1998. Slom politike katoličkog jugoslavenstva. Hrvatska pučka stranka u političkom životu Kraljevine SHS (1919. - 1929.) [Biblioteka Hrvatska povjesnica, III. Monografije i studije, sv. 7]. Zagreb: Hrvatski institut za povijest, Dom i svijet.

MATIJEVIĆ, Zlatko (ur.). 2002. Hrvatski katolički pokret. Zbornik radova s Međunarodnoga znanstvenog skupa održanog u Zagrebu i Krku od 29. do 31. ožujka 2001. Zagreb: Kršćanska sadašnjost, Vijeće za laike Hrvatske biskupske konferencije.

MATIJEVIĆ, Zlatko. 2002a. Alfirević, Ante. U MATIJEVIĆ 2002: 790.

MATIJEVIĆ, Zlatko. 2002b. Binički, Fran. U MATIJEVIĆ 2002: 795.

MATIJEVIĆ, Zlatko. 2002c. Butković, Ivan. U MATIJEVIĆ 2002: 799.

PIRC, Jožko. 1990. Rimski katolik in ločitev duhov. U Mahničev simpozij v Rimu, ur. Edo Škulj, 109-126. Zagreb-Celje: Slovenska teološka akademija u Rimu, Mohorjeva družba u Celju, Mohorjeva družba u Gorici, Kršćanska sadašnjost u Zagrebu.

RADIĆ, Ignacij. 1940. Doktor Antun Mahnić, biskup krčki. Slavonska Požega: Naklada „Dobra štampa“.

STRECHA, Mario. 1997. Katoličko hrvatstvo. Počeci političkog katolicizma u banskoj Hrvatskoj (1897. - 1904.) [Homines, tempora, loci]. Zagreb: Barbat.

ŠAGI-BUNIĆ, Tomislav Janko. 1970. Mahničeva poruka današnjim katolicima u Hrvatskoj. Svesci Kršćanske sadašnjosti 17/18: 118-119. 
ŠANJEK, Franjo. 1996. Kršćanstvo na hrvatskom prostoru. Pregled religiozne povijesti Hrvata (7. - 20. st.) [Priručnici - Biblioteka Centra za koncilska istraživanja, dokumentaciju i informacije „Kršćanska sadašnjost“”, sv. 27]. II. prerađeno i dopunjeno izdanje. Zagreb: Kršćanska sadašnjost.

\section{Ignacij(e) Radić's Account of the Croatian Catholic Movement}

Ignacij Radić (St. Vid near Malinska, 28 ${ }^{\text {th }}$ August 1876 - Porat, $30^{\text {th }}$ July 1965), a Glagolitic monastic tertiary, became a priest in 1899 and worked first in Veli Lošinj as a RI teacher, then as a professor in high schools in Galevac and Krk administered by his religious community. From the very beginning of Mahnić's Croatian Catholic Movement in 1897 Radić joined him and was very active as one of the main contributors to the journal Hrvatska straža (1903). Upon his arrival at Krk, Mahnić chose him as his personal confessor and accepted his help in editing the publications Hrvatska straža and Svećenička zajednica. Loyal to Mahnić's priniciple that the Church must follow the whole of human activities and give to its followers gospel guidelines for life and formation of Christian views, he studied the social dynamics of his country and the world writing texts with philosophical, social and ascetic agenda. His close ties with bishop Mahnić showed in the difficult times for the Croatian Catholic Movement during the World War I. He supported Mahnić completely and shared his fears not only about the fate of the movement, but also of the Catholic community and political self-determination of the South Slavs at the time of the breakdown of the Habsburg Empire and the making of the State of Slovenians, Croats and Serbs. Radić's book Antun Mahnić, biskup krčki (Antun Mahnić, bishop of Krk, Slavonska Požega 1940) provides a valuable testimony to Mahnić's role in the emergence and activity of the Croatian Catholic Movement up till his death (1850 - 1920), especially in the aforementioned times of crisis.

Keywords: Antun Mahnić, Ignacij Radić, Croatian Catholic Movement, Hrvatska straža, personal confessor of bishop Mahnić

Ključne riječi: Antun Mahnić, Ignacij Radić, Hrvatski katolički pokret, Hrvatska straža, biskupov ispovjednik

Franjo Emanuel Hoško Teologija u Rijeci Područni studij Katoličkoga bogoslovnog fakulteta Sveučilišta u Zagrebu HR-510000 Rijeka, Omladinska 14 emanuel.hosko@ofm.hr 


\section{FILOZOFSKI FAKULTET SVEUČILIŠTA U ZAGREBU \\ ZAVOD ZA HRVATSKU POVIJEST \\ INSTITUTE OF CROATIAN HISTORY \\ INSTITUT FÜR KROATISCHE GESCHICHTE}
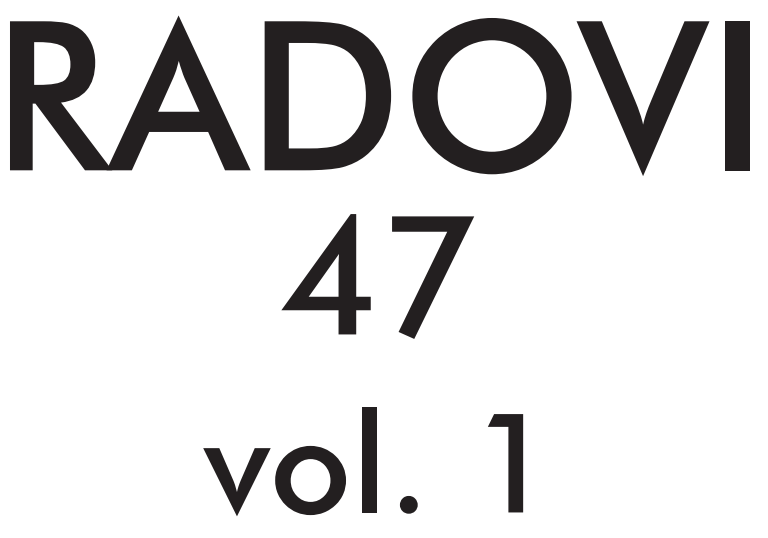

ZAVOD ZA HRVATSKU POVIJEST

FILOZOFSKOGA FAKULTETA SVEUČILIŠTA U ZAGREBU

\section{PF press \\ ZAGREB 2015.}




\title{
RADOVI ZAVODA ZA HRVATSKU POVIJEST FILOZOFSKOGA FAKULTETA SVEUČILIŠTA U ZAGREBU
}

\author{
Knjiga 47, vol. 1
}

\author{
Izdavač / Publisher \\ Zavod za hrvatsku povijest \\ Filozofskoga fakulteta Sveučilišta u Zagrebu \\ FF-press \\ Za izdavača / For Publisher \\ Vlatko Previšić \\ Glavni urednik / Editor-in-Chief \\ Hrvoje Gračanin \\ Izvršna urednica / Executive Editor \\ Inga Vilogorac Brčić \\ Uredništvo / Editorial Board
}

Bruna Kuntić-Makvić (stara povijest/ancient history), Zrinka Nikolić Jakus (srednji vijek/ medieval history), Hrvoje Petrić (rani novi vijek/early modern history), Željko Holjevac (moderna povijest/modern history), Tvrtko Jakovina (suvremena povijest/contemporary history),

Silvija Pisk (mikrohistorija i zavičajna povijest/microhistory and local history),

Zrinka Blažević (teorija i metodologija povijesti/theory and methodology of history)

Međunarodno uredničko vijeće / International Editorial Council

Denis Alimov (Sankt Peterburg), Živko Andrijašević (Nikšić), Csaba Békés (Budapest), Rajko Bratož (Ljubljana), Snježana Buzov (Columbus, Ohio), Svetlozar Eldarov (Sofija), Toni Filiposki (Skopje), Aleksandar Fotić (Beograd), Vladan Gavrilović (Novi Sad), Alojz Ivanišević (Wien),

Egidio Ivetić (Padova), Husnija Kamberović (Sarajevo), Karl Kaser (Graz),

Irina Ognyanova (Sofija), Géza Pálffy (Budapest), Ioan-Aurel Pop (Cluj),

Nade Proeva (Skopje), Alexios Savvides (Kalamata), Vlada Stanković (Beograd), Ludwig Steindorff (Kiel), Peter Štih (Ljubljana)

Izvršna urednica za tuzemnu i inozemnu razmjenu / Executive Editor for Publications Exchange Kristina Milković

Tajnik uredništva / Editorial Board Assistant

Dejan Zadro

Adresa uredništva/Editorial Board address

Zavod za hrvatsku povijest, Filozofski fakultet Zagreb, Ivana Lučića 3, HR-10 000, Zagreb

Tel. ++385 (0)1 6120 150, 6120 158, faks ++385 (0)1 6156879

Časopis izlazi jedanput godišnje / The Journal is published once a year

Časopis je u digitalnom obliku dostupan na / The Journal in digital form is accessible at Portal znanstvenih časopisa Republike Hrvatske „Hrčak“ http://hrcak.srce.hr/radovi-zhp

Financijska potpora za tisak časopisa / The Journal is published with the support by

Ministarstvo znanosti, obrazovanja i športa Republike Hrvatske

Časopis je indeksiran u sljedećim bazama / The Journal is indexed in the following databases:

Directory of Open Access Journals, EBSCO, SCOPUS, ERIH PLUS 
Naslovna stranica

Iva Mandić

Grafičko oblikovanje i računalni slog

Marko Maraković

Lektura

Samanta Paronić

Tisak

Web2tisak, Zagreb

Naklada

250 primjeraka

Časopis je u digitalnom obliku dostupan na Portalu znanstvenih časopisa Republike Hrvatske ,Hrčak“ http://hrcak.srce.hr/radovi-zhp

The Journal is accessible in digital form at the Hrcak - Portal of scientific journals of Croatia http://hrcak.srce.hr/radovi-zhp 


\section{RADOVI 47}

\section{vol. 1}

ZaVoda za hrVAtSku poviJest FILOZOFskoga fakulteta SVeuČILIŠTA u Zagrebu 


\title{
Tematski blok / Themed issue
}

\section{TREĆOREDSKA GLAGOLJAŠKA TRADICIJA U EUROPSKOM KONTEKSTU TERTIARY GLAGOLITIC TRADITION IN EUROPEAN CONTEXT}

\author{
Radovi međunarodnoga znanstvenog skupa \\ održanoga 27. i 28. IX. 2013. na Hrvatskom katoličkom sveučilištu u Zagrebu \\ u organizaciji \\ Provincije franjevaca trećoredaca glagoljaša u Zagrebu, Hrvatskoga katoličkog \\ sveučilišta u Zagrebu, Filozofskoga fakulteta Sveučilišta u Zagrebu - Odsjek za \\ povijest, Filozofskoga fakulteta Sveučilišta u Splitu - Odsjek za povijest, Instituta \\ za povijest umjetnosti u Zagrebu i Staroslavenskoga instituta u Zagrebu \\ Proceedings of the International Scientific Conference \\ held on 27th and 28th September 2013 at the Catholic University of Croatia in Zagreb \\ and organized by \\ the Province of the Glagolitic Friars of the Third Order Regular, Catholic University \\ of Croatia in Zagreb, Faculty of Humanities and Social Sciences of the University \\ of Zagreb - Department of History, Faculty of Humanities and Social Sciences of \\ the University of Split - Department of History, Institute of Art History, \\ and Old Church Slavonic Institute
}

Gosti urednici / Guest editors

\author{
Ivan BOTICA \\ Tomislav GALOVIĆ \\ Kristijan KUHAR
}

